JELTL (Journal of English Language Teaching and Linguistics) e-ISSN: 2502-6062, p-ISSN: 2503-1848

2020, Vol. 5(3)

www.jeltl.org

\title{
Future English Teachers' Perspective towards the Implementation of E-Learning in Covid-19 Pandemic Era
}

\author{
Reza Pustika \\ Universitas Teknokrat Indonesia \\ reza_pustika@teknokrat.ac.id
}

\begin{abstract}
This research was conducted to investigate the future English teachers' perspective towards the implementation of e-learning in Covid-19 pandemic era. There were 60 respondents involved in this research. A survey method was carried out in this research. The data of this research was collected by distributing a questionnaire. The questionnaire was formulated based on the theories about the pros and cons of the e-learning implementation. Descriptive analysis was done to analyzed this research data. The data of this research was transformed into percentage. The result of this research showed that the future English teachers find elearning is beneficial for them, but still have some lacks to overcome. Besides, the subjects of this research are aware of things they need to prepare before they conduct e-learning, and they also suggest the stakeholders in Indonesia to improve the technology development to support the e-learning implementation.
\end{abstract}

Keywords: Future English teachers, perspective, e-learning, Covid-19

\section{INTRODUCTION}

Covid-19 pandemic is a phenomenon that appears in 2019 and continues in 2020. Every person from every country in the world is familiar with this phenomenon. Covid-19 is a disease that attacks many people from all over the world. Due to this phenomenon, most aspects in humans' life has changed. People in 2020 are not allowed to gather in one place. They are obliged to keep their distance from one to another. This also affects the education aspect not only in Indonesia but also in other countries. An education without gathering both students and the teacher seems impossible. Covid-19 Pandemic also forces people to do social distancing meaning there is no face-to-face interaction while interaction is one of 


\section{Reza Pustika}

important features in teaching and learning process. Interaction is a salient pattern where both teachers and students come into contact to share information and knowledge, especially in language classrooms. It raises the effectiveness of language teaching-learning process, as there is the involvement of two-way interaction and an active participation between teachers and students in the classroom activities (Rido \& Sari, 2018).

Something that seemed impossible before appears to be possible now. The implementation of e-learning becomes a new regulation in Indonesia to overcome the lack of meeting in the classroom. To implement e-learning, technology becomes primary needs. Technology is not necessarily a new thing in humans' life. Most people now, even children, are able to use and operate technology in life. It makes children called as digital native which means they can master the technology better than adult (Oktaviani \& Desiarti, 2017).

Education needs technology now more than ever. Foreign language students, particularly in Indonesia, have experienced the substantial of teaching and learning process inside the classroom because of the technology development in the education field. Nowadays, most of foreign language students learn and acquire the target language primarily through online learning or blended learning (Sari \& Wahyudin, 2019).

The implementation of e-learning in Indonesia especially is a quite new thing. The development of technology and facility in Indonesia is not equal yet as Indonesia is such a huge country. However, teachers in Indonesia have to adapt to this situation fast. They have to master various application as well as platform that support their e-learning with their students.

This article is trying to figure out the perspective of future English teacher about the implementation of e-learning today. Many previous studies have investigated the perceptions from students experiencing online learning. Some studies claim that the implementation of elearning has positive impact to students', some other studies find that the implementation of e-learning has problems.

Studies conducted by Coldwell-Nelson and Craig (2006), Luaran, et.al (2014), Cakrawati (2017), and Sukmawati, et.al (2020) emphasized that e-learning is flexible as it provides students materials that can be accessed anywhere and anytime. Studies done by Sit, et.al (2005), Nwankwo (2015), and Fedynich, Bradley, and Bradley (2015) found another result from the implementation of e-learning. Interaction between the teacher and learners is a challenge for all online teachers to be considered in the implementation of e-learning. To implement e-learning, technology becomes one of important influences. However, a study from Amir, et.al (2020) agreed that pedagogy strategies should be utilized in the implementation of e-learning.

Beside the positive impacts of e-learning implementation, constraints were found in its implementation. Some constraints found are the availability of internet connection, accessibility of teaching media, and accessible learning tools (Agung \& OP, 2020). The availability of internet connection in rural areas still becomes one of biggest challenges in the implementation of e-learning. Moreover, a surprising fact from studies conducted by Bali and Liu (2018), Adnan and Anwar (2020), and Setyaningsih (2020) state that online learning cannot produce expected results. The face-to-face interaction in the classroom produces better performances. Despite the challenges faced in the implementation of e-learning, Yee 
(2011) and Bagata, Umamah, and Fikri (2020) found students share positive perception as well as improve their self-motivation in joining online learning.

The last semester students of English Education study program is chosen to be the subject for this research because they are the teachers that will face this e-learning process later on. This is important to see their readiness to implement e-learning later on.

\section{LITERATURE REVIEW}

\subsection{The Definition of E-Learning}

Sadeghi (2019) defines e-learning or distance education as the type of education in where learners may not always be physically coming to the school. In other words, they still can learn without having to attend the class or university campus. However, Sadeghi (2019) argues that distance learning might not be the finest choice for every student who tries to take a college degree or university program.

On the other hand, Traxler (2018) argues that distance education may be beneficial for widening access to higher education. Besides, distance education can increase the diversity of student population because today's technologies enable people to learn anywhere, anytime from anyone. It means that students from other countries can attend virtually to the online classroom provided by certain colleges.

Rossi (2009) believes that e-learning as a concept covers a range of applications, learning methods, and processes. The use of applications, new multimedia technologies, and the internet in online learning is essential as it supports the implementation of e-learning to ease students access the material provided or attend the virtual meeting easily (Oblinger and Hawkins, 2005; the European Commission, 2001; Arkorful \& Abaidoo, 2014). In its broadest sense, Abbad et al (2009), define e-learning as any learning that is enabled electronically. Much deeper, Algahtani (2011) proposes computer-based and internet based e-learning as two basic types of e-learning.

\subsection{Advantages of E-Learning}

Sadeghi (2019) proposes some advantages of the e-learning implementation. Elearning enables students to study from anywhere at anytime. In the implementation of elearning, the schedule is flexible. Students may manage their own schedule based on their own availability. Moreover, students can flexibly access the material from their home without necessarily coming to the classroom. The adoption of e-learning enables the institutions and their students to deliver, receive and choose learning programs since the implementation of e-learning gives much flexibility of time and place (Semdley, 2010). By learning virtually and choosing the class based on their own availability, students can save their time.

Brown (2017) believes that the e-learning implementation can save students' amount of money significantly. Moreover, the course offered at traditional education centers are more expensive than than the courses provided at distance or online learning. Besides, Nagrale (2013) states that students attending e-learning do not have to commute in crowded buses or local trains. E-learning is cost effective in the sense that there is no need for the students or learners to travel (Arkorful \& Abaidoo, 2014). Brown (2017) also emphasizes that e-learning students can earn their livelihood along with improving their qualification as distance learning will 


\section{Reza Pustika}

accommodate both learning as well as earning. Lastly, e-learning enables students to access and share materials easily, either through direct upload to a ready-made cloud storage, or distributed via a social network of any kind (both formal and informal), enhancing thus student collaboration, especially in group or project-based learning settings (Zounek, \& Sudicky, 2012).

\subsection{Disadvantages of E-Learning}

According to Bijeesh (2017), without face-to-face interaction in the classroom and no classmates who are possibly able to help and remind the e-learning students, pending assignments, and losing track of deadlines are high. Therefore, Arkorful and Abaidoo (2014) still emphasizes that social interaction in a learning process is essential. It enables students to have opportunities for relations among students by the use of discussion forums. However, e-learning may help exclude obstacles that are potential to hinder participation including the fear of talking to other learners. As students and the teacher are not meeting face to face, it would be a little bit difficult to control or regulate bad activities like cheating. Therefore, online teachers must carry a good communication with their students on e-learning programs, since this type of study involves the increasing use of asynchronous video communication, as well as a lack of personal contact, which is essential for the development of trust (Dennen, Aubteen Darabi, \& Smith, 2007).

\section{RESEARCH METHODS}

The type of this research is survey research since the objective of this research is to investigate the future English teachers' perspective toward the implementation e-learning in covid-19 pandemic era. Survey approach is used when the researcher wants to gather opinions, beliefs, or perceptions about a current issue from a large group of people (Lodico, Spaulding, and Voegtle, 2010). This research was conducted in Lampung, Indonesia.

There were 60 English education study program students involved in this research. The instrument used in this research was a questionnaire. The questionnaire was formulated based on the theories portrayed in the literature review stating the pros and cons of elearning implementation. There were 10 items in the questionnaire. 2 statements were an open-ended statement, while the 8 other statements were closed-ended statements. An openended statement allows the subject of research to give further opinion about the statement. A close-ended statement requires the subject of research to only choose "agree", "neutral", or "disagree". The data of this research were analyzed descriptively. The researcher tried to find out the perspective of the respondents toward the implementation of e-learning in covid19 pandemic era.

\section{FINDINGS}

The Likert-scale questionnaire that had 8 items of the question was used to gather the data for this research. The respondents also had opportunities to give deep and comprehensive responses in answering 2 open-ended questions. The questions and statements used in the questionnaire are presented as follows: 
Future English Teachers' Perspective towards the Implementation of E-Learning

Table 1. List of Questions and Statements used in Questionnaire

\begin{tabular}{|c|l|}
\hline No. & \multicolumn{1}{c|}{ Questions and Statements } \\
\hline 1 & $\begin{array}{l}\text { You are now living in technology era, as a future English teacher, what things } \\
\text { you should prepare to implement e-learning in your own classroom later on? }\end{array}$ \\
\hline 2 & $\begin{array}{l}\text { What suggestions you would like to utter to stakeholders in Indonesia } \\
\text { regarding to the implementation of e-learning now? }\end{array}$ \\
\hline 3 & E-learning allows students to learn anywhere at anytime. \\
\hline 4 & E-learning builds social interaction. \\
\hline 5 & $\begin{array}{l}\text { Students' expenses on travel or commuting are decreasing because they can } \\
\text { learn from home. }\end{array}$ \\
\hline 6 & Students' expenses on internet data burden them. \\
\hline 7 & $\begin{array}{l}\text { Students are able to work in order to earn money while they are taking e } \\
\text { learning from home. }\end{array}$ \\
\hline 8 & $\begin{array}{l}\text { Technology development (signal and electricity) in Indonesia enables students } \\
\text { to join e-learning. }\end{array}$ \\
\hline 9 & Cheating is commonly found in the implementation of e-learning. \\
\hline 10 & Sharing the material is easier in e-learning process. \\
\hline
\end{tabular}

Questions number 1 and 2 are open-ended questions. In responding these questions, subjects of research were able to give deeper and more comprehensive response. Meanwhile, statements number 3 up to 10 are close-ended questions in which the subject of research might choose "agree", "neutral", or "disagree" in responding these statements. The responses from statements number 3 up to 10 were transformed into percentages to ease the interpretation.

The first question from the research questionnaire is" You are now living in technology era, as a future English teacher, what things you should prepare to implement elearning in your own classroom later on?". In responding this question, the respondents were aware that they needed to define the objective first in order to make teaching and learning process meaningful. They believed that learning process needs to be useful as well as meaningful to their students even though the learning process is held virtually. Related to classroom preparation, the respondents of this research agreed that syllabus should be constructed and teaching media should be chosen as well. In relation to the implementation of e-learning, they argued that English teachers in this virtual era should be creative to hinder their students from boredom. Moreover, English teachers have to know which application, website, and platform that will be easy-to-use and helpful for their students. Although teachers and students cannot manage to have teaching and learning process in the classroom, it is now possible to still have learning process by using some application, website, and other platforms provided now. Therefore, English teachers should be able to stimulate discussion.

"What suggestions you would like to utter to stakeholders in Indonesia regarding to the implementation of e-learning now?" is the second question from the research questionnaire. Since the setting of research is in Lampung, Indonesia, respondents tended to have similar response to this question. Respondents believed that facilities including signal and electricity in Indonesia should be contributed equally as they were aware that Indonesia is such a huge country. They expected the facilities are available for all students both in city and village. This result is in line with the previous study conducted from Agung and OP (2020) who state 


\section{Reza Pustika}

that the availability of internet connection becomes one big constraint in the implementation of e-learning. In addition, respondents of this research found it essential if teachers in Indonesia are invited to join training program or workshop to support their preparation to implement e-learning.

To ease the interpretation, responses from statements number 3 up to 10 were transformed into percentages. The result of this research is presented in Table 2.

Table 2. Responses from Statements Number 3-10 in the Research Questionnaire

\begin{tabular}{|l|l|c|c|c|}
\hline No. & \multicolumn{1}{|c|}{ Statements } & Agree & Neutral & Disagree \\
\hline 3 & E-learning allows students to learn anywhere at anytime. & $\mathbf{7 5 \%}$ & $25 \%$ & $0 \%$ \\
\hline 4 & E-learning builds social interaction. & $22 \%$ & $\mathbf{4 1 \%}$ & $37 \%$ \\
\hline 5 & $\begin{array}{l}\text { Students' expenses on travel or commuting are decreasing } \\
\text { because they can learn from home. }\end{array}$ & $\mathbf{5 7 \%}$ & $40 \%$ & $3 \%$ \\
\hline 6 & Students' expenses on internet data burden them. & $\mathbf{5 7 \%}$ & $37 \%$ & $6 \%$ \\
\hline 7 & $\begin{array}{l}\text { Students are able to work in order to earn money while } \\
\text { they are taking e learning from home. }\end{array}$ & $43 \%$ & $\mathbf{4 5 \%}$ & $12 \%$ \\
\hline 8 & $\begin{array}{l}\text { Technology development (signal and electricity) in } \\
\text { Indonesia enables students to join e-learning. }\end{array}$ & $23 \%$ & $\mathbf{5 8 \%}$ & $19 \%$ \\
\hline 9 & $\begin{array}{l}\text { Cheating is commonly found in the implementation of e- } \\
\text { learning. }\end{array}$ & $\mathbf{5 2 \%}$ & $40 \%$ & $8 \%$ \\
\hline 10 & Sharing the material is easier in e-learning process. & $\mathbf{5 7 \%}$ & $38 \%$ & $5 \%$ \\
\hline
\end{tabular}

\section{DISCUSSION}

The questionnaire of this research consisted of two question types. Questions number 1 and 2 required the subject of research to give their comprehensive opinion, while statements number 3 up to 10 allowed the subject of research to choose "agree", "neutral", or "disagree". There were 60 respondents giving their response to this research.

From the research result, it can be shown that $75 \%$ of respondents believe that by learning virtually, they can access the learning material from anywhere at any time. This flexibility is in line with what Sadeghi (2019), Coldwell-Nelson and Craig (2006), Luaran, et.al (2014), Cakrawati (2017), and Sukmawati, et.al (2020) as those researchers have emphasized that e-learning is flexible as it provides students materials that can be accessed anywhere and anytime.

$57 \%$ from the 60 respondents involved in this study agree that their expenses on travel and commuting is decreasing since they started learning virtually. The decreasing expenses that students experience has already been anticipated by some experts (Brown, 2017; Smedley, 2010; Nagrale, 2013; and Arkorful \& Abaidoo, 2014). However, as the e-learning implementation requires internet connection, $57 \%$ respondents from this study find that their expenses on internet data burden them. This finding has been anticipated by Agung and OP (2020) as they believe that the availability of internet connection becomes one of constraints that students will highly face in the implementation of e-learning.

One disadvantage of the implementation of e-learning that the respondents of this research agree is that cheating is commonly found. Arkorful and Abaidoo (2014) argue that 
implementing e-learning might be difficult because teachers cannot control or regulate bad activities like cheating. 57\% respondents of this research believe that e-learning eases them to share the material that has been discussed. This finding supports what Zounek, \& Sudicky (2012) propose.

Studies from Sit, et.al (2005), Nwankwo (2015), Fedynich, Bradley, and Bradley (2015), and Arkorful and Abaidoo (2014) claim that social interaction is rarely taken place in the implementation of e-learning. Their findings were slightly different from this finding's as the $41 \%$ respondents from this research are doubt to extremely agree or disagree with this theory. In today's e-learning, many platforms can be used to support the learning process. Students and the teacher can still have conversation virtually.

Having part-time job is commonly found today. Many college students have job to earn more money. Learning virtually can be an advantage for those who have part-time job. However $45 \%$ respondents from this research are not sure about that. This doubt can be probably derived from the existence of covid-19 pandemic that causes them to stay at home. Lastly, related to technology and facilities in Indonesia, 58\% respondents have to think twice whether the facilities in Indonesia have supported the implementation of e-learning in Indonesia.

\section{CONCLUSION}

The perspective of future English teachers involved in this research is worth knowing since the teaching and learning process in the future is on their hands. The future English teachers have to be aware of what they will face by following the rapid development of technology. Both advantages and disadvantages of e-learning that they have experienced might be reflection for them to improve and support their e-learning process later on. Further research can be conducted by inviting different subject of research to see more various perspective from various field of knowledge.

\section{REFERENCES}

Abbad, M. M., Morris, D., \& de Nahlik, C. (2009). Looking under the Bonnet: factors affecting student adoption of E-Learning systems in Jordan. The International Review of Research in Open and Distance Learning.

Adnan, M., \& Anwar, K. (2020). Online learning amid the COVID-19 pandemic: Students' perspectives. Journal of Pedagogical Sociology and Psychology.

Agung, A.S.S.N., Surtikanti, M.W., \& OP, C.A.Q. (2020). Students' perception of online learning during COVID-19 pandemic: A case study on the English students of STKIP Pamane Talino. Journal of Social Sciences and Humanities, Vol. 10, No. 2.

Algahtani, A.F. (2011). Evaluating the Effectiveness of the E-learning Experience in Some Universities in Saudi Arabia from Male Students' Perceptions. Durham theses, Durham University.

Amir, L.R., Tanti, I., Maharani, D.A., Wimardhani, Y. S., Julia, V., Sulijaya, B., \& Puspitawati, R. (2020). Student perspective of classroom and distance learning during 
Reza Pustika

COVID-19 pandemic in the undergraduate dental study program Universitas Indonesia. BMC Medical Education, 20-392.

Arkorful, V. \& Abaidoo, N. (2014). The role of e-learning, the advantages and disadvantages of its adoption in Higher Education. International Journal of Education and Research Vol. 2 No. 12 December 2014

Bagata, D.T.R., Umamah, A., \& Fikri, D. (2020). EFL university students' perception of the use of online learning platform in the covid 19 pandemic. Jurnal Penelitian, Pendidikan, dan Pembelajaran, Vol. 15, No. 34.

Bali, S., \& Liu, M.C. (2018). Students' perceptions toward online learning and face-to face learning courses. MISEIC.

Bijeesh, N. A. (2017). Advantages and disadvantages of distance learning. Retrieved from http://www.indiaeducation.net/online education/articles/advantages-anddisadvantages-of-distancelearning.html Retrieved on October 21st 2020 at 2.00 PM

Brown, C. (2017). Advantages and disadvantages of distance learning. Retrieved from https://www.eztalks.com/elearning/advantages-and-disadvantages-of-distancelearning.html retrieved on October 21st 2020 at 2.55 PM

Cakrawati, L.M. (2017). Students' perceptions on the use of online learning platforms in EFL classroom. English Language Teaching and Technology Journal (ELT-Tech Journal).

Coldwell-Nelson, J., \& Craig, A. (2006). Student perspective of online learning. ALT-C 2006 Research Proceedings.

Dennen, V. P., Aubteen Darabi, A., \& Smith, L. J. (2007). Instructor-learner interaction in online courses: The relative perceived importance of particular instructor actions on performance and satisfaction. Distance Education, 28(1), 65-79.

European Commission (2001). The eLearning Action Plan: Designing tomorrow's education. http://www.elearningeuropa.info.

Fedynich, L., Bradley, K.S., \& Bradley, J. (2015). Graduate students' perceptions of online learning. Research in Higher Education Journal.

Lodico, M.G., Spaulding, D.T., \& Voegtle, K.H. (2010). Methods in Educational Research: From Theory to Practice $\left(2^{\text {nd }} E d\right)$. San Fransisco: A Wiley Imprint.

Luaran, J.E., Samsuri, N. N. Nadzri, F. A., Rom, K. B. M. (2013). A study on the student's perspective on the effectiveness of using e-learning. Procedia - Social and Behavioral Sciences 123 (2014) 139-144.

Nagrale, P. (2013). Advantages and disadvantages of distance education. https://surejob.in/advantages-anddisadvantages-of-distance-education.html Retrieved on October 21st 2020 at 2.50 PM

Nwankwo, A.A. (2015). Students' learning experiences and perceptions of online course content and interactions (A Dissertation, Walden University, Minneapolis, US). Retrieved from https://scholarworks.waldenu.edu/cgi/viewcontent.cgi?article=1187\&context=disserta tions

Oblinger, D. G., \& Hawkins, B. L. (2005). The myth about E-learning. Educause review. 
Future English Teachers' Perspective towards the Implementation of E-Learning

Oktaviani, L., \& Desiarti, E.M. (2017). A lecturer's and students' perspective toward ethnic snake game in speaking class at Universitas Muhammadiyah Malang. Teknostatik, vol. 15 (02).

Rido, A., \& Sari, F.M. (2018). Characteristics of classroom interaction of english language teachers in Indonesia and Malaysia. International Journal of Language Education, Vol. 2 No. 1, 2018 pp. 40-50.

Rossi.P.G. (2009). Learning environment with artificial intelligence elements. Journal of elearning and knowledge society, 5(1), 67-75.

Sadeghi, M. (2019). A Shift from classroom to distance learning: Advantages and limitations. International Journal of English Education (4:1).

Sari, F.M., \& Wahyudin, Y. A. (2019). Blended-Learning: The responses from non-English students in the Indonesian tertiary context. Teknostatik, Vol. 17 (1).

Setyaningsih, E. (2020). Face-to-face or online learning: Students' perspectives on blended learning in Indonesia. Journal of English Language Studies Vol. 5, No.1.

Sit, J.W.H., Chung, J.W.Y., Chow, M.C.M., \& Wong, T.K.S. (2005). Experiences of online learning: students' perspective. Nurse Education Today.

Smedley, J.K. (2010). Modelling the impact of knowledge management using technology. OR Insight (2010) 23, 233-250.

Sujarwo., Sukmawati., Akhiruddin., Ridwan., \& Siradjuddin. (2020). An analysis of University students' perspective on online learning in the midst of COVID-19 pandemic. Jurnal Pendidikan dan Pengajaran.

Traxler, J. (2018). Distance learning: Predictions and possibilities. Educ. Sci, 8(1), 35.

Yee, R.C.S. (2011). Perceptions of online learning in an Australian University: Malaysian students' perspectives, (A Thesis, Queensland University of Technology, Brisbane, Australia). Retrieved from http://www.ijiet.org/papers/573-I012.pdf

Zounek, J. \& Sudicky, V. (2012). Heads in the cloud: Pros and Cons of online learning. Elearning: Learning with online technologies (2012). 